\title{
NEW METHODOLOGICAL RESEARCH IN THE STORIES OF THE IRAQIAN MODERN STORYER AHMAD IBRAHIM (ON THE EXAMPLE OF "NIDO" AND "DARD" STORIES)
}

\author{
Sarviniso Rozibobo Kizi Mamanazarova \\ Teacher Of Arabic Language, Tashkent State University Of Oriental Studies, Uzbekistan
}

\section{ABSTRACT}

This article discusses in detail the nature and novelty of the works of art in Iraqi storytelling in the second half of the twentieth century and the methodology used by Iraqi storyteller Ahmad Ibrahim ("Cry" and "Pain"). Also, an in-depth analysis of the extent to which the features of psychological realism in the stories "Cry" and "Pain are revealed through their artistic possibilities reveals the richness of the theme of immigration in the story Dard. Although the uniqueness of a writer's work is in the form of poetry, it is in fact a prose, which emphasizes the writer's high talent, and as a result, requires scientific work on the subject.

KEYWORDS: - Artistic and philosophical study, the relationship of form and content, the concept of man and society, man and being, the hero, the image of the "sea", prose, poetry, inner manologue, fantasy, poetry, artistic iniko , psychological realism, artistic image.

\section{INTRODUCTION}

The uniqueness of creation is determined by the artistic and philosophical study and mastery of the psychology of the individual and society, new landscapes and aspects of reality, new layers of the soul. The aesthetic ideal and the novelty of meaning that emerge in this process define the unique nature of artistic creation. One such contemporary Iraqi storyteller is Ahmad Ibrahim, a writer of Iraqi descent who lived and worked far from home. The main idea of his stories is the longing for the homeland, the contradictions between society and man, the feelings of the heart, the transience of life. Although Ahmad Ibrahim's stories are formally reminiscent of poetry, they are in fact prose. Similar styles can be found in Arabic literature today. Especially in recent years, there has been a growing tendency in modern Iraqi literature to portray life and reality in a variety of poetic genres and forms.
This is reflected in the work of Ahmad Ibrahim. We get to know Ahmad Ibrahim's work through his stories "Cry", "Pain", and "Single" and "One Sentence" in the collection of short stories "Return".

\section{Methodology}

\section{Goals and objectives}

The aim of this study is to study the modern storytelling in Iraq through the work of Ahmad Ibrahim and to identify its traditional and artistic features. The scale of the themes in Ahmad Ibrahim's stories necessitates the task of covering a set of social, spiritual, and moral problems posed to artistic perception.

\section{Methods}


CURRENT RESEARCH JOURNAL OF PHILOLOGICAL SCIENCES 2(8): 39-44,

May 2021 DOI: https://doi.org/10.37547/philological-crjps-02-08-10

ISSN 2767-3758

(C)2021 Master Journals

Crossref do: 81 Google

Accepted $26^{\text {th }}$ August, 2021 \& Published $31^{\text {th }}$ August, 2021

Based on the goals and objectives of the article, the methods of comparative-historical, comparativetypological analysis were used.

\section{Results}

In the works of Ahmad Ibrahim, one of the brightest representatives of modern Arabic literature, one can observe some kind of pain, anguish, anguish. One of Ahmad Ibrahim's unique stories is Nido. It is known that every artist is in tune with the time in which he lives, and this, of course, affects his work. Ahmad Ibrahim was able to have his say about being and man in the story of Nido. This story skillfully depicts the contradictions between people, between man and society, between man and being. The mental state of the protagonist is inextricably linked with nature. Especially today, the Iraqi state is in a very difficult situation. It is through the story of Nido that the author reveals the relationship between the individual and society. The main content of the story of Nido is human psychology - it is illuminated through the relationship between the individual and society. Through this story, the author describes the transience of life as a guest, the value of time and the main content of the story.

The story is told through the author's speech.

The story begins with these lines.
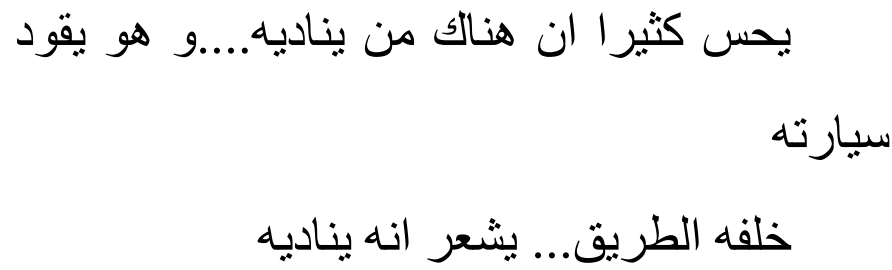

يقاوم احساسا يتملكه ان يفتح باب السيارة و

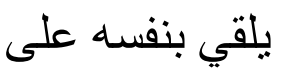

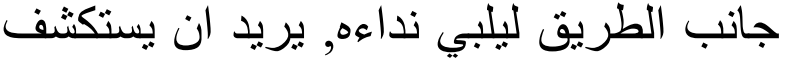

افقا جديدا لم

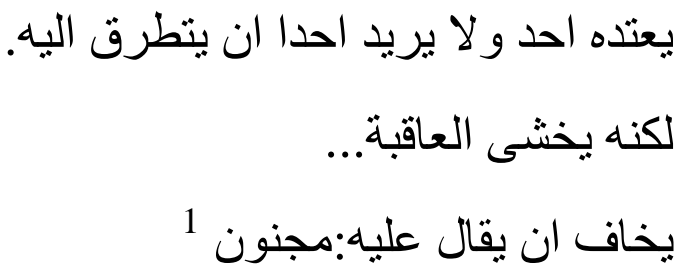

He feels the urge to call him there ........

And he is driving his car....

The road is behind him.

She feels like she's calling him.

This is how the story begins, inviting the reader to observe.

To respond to his call, he struggles with a feeling that makes him open the car door and throw himself on the side of the road.

He wants to explore a new horizon where no one has wronged him and no one can find his way there.

But she is afraid of the consequences.

She's afraid he'll be called a lunatic ${ }^{2}$.

It can be seen from the beginning of the story that the story describes the path of a person in life and the inner struggle in the human psyche through an inner call. The protagonist is driving and discussing his inner experiences with himself. He is struggling with the feelings that are crushing him from within. As we read the rest of the story, our understanding becomes clearer.

The author is the protagonist of the story. We see this in the lines of his story. Because in the process of getting acquainted with the work of the writer, he was far from where he was born and raised.

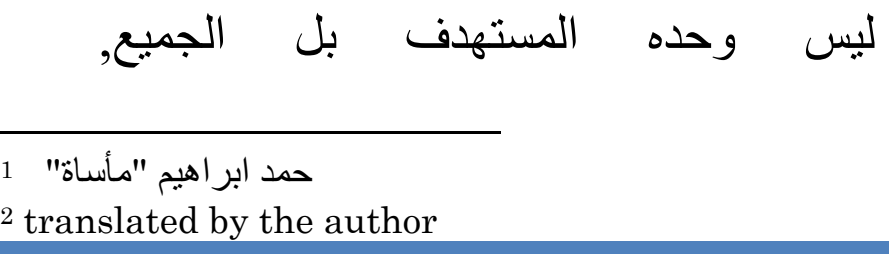




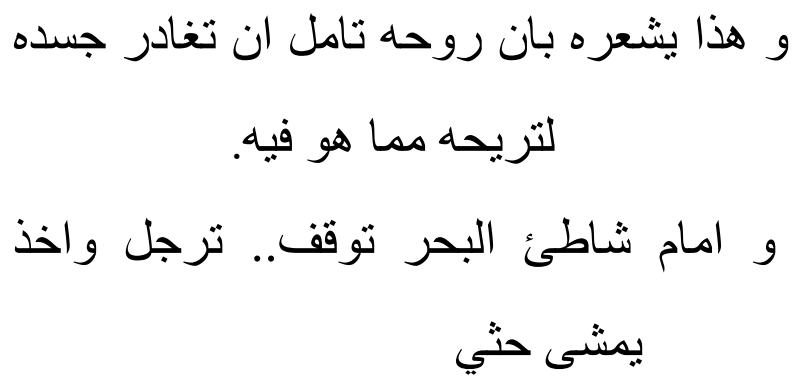

و اطال نظرة بعيدا بعيدا بعيدا, الى نقطة التقاء

السماء بالبحر الى ذلك الافق البعيد و كأنه يلقى عن كاهليه

دائما يثير البحر شجونه يذكره بمن رحلو ا.. ذللك الضيق الذي يخنقه و يكبل حركته. بمن كانوا اعز ما بملك لم يبق منهم سوى اورق

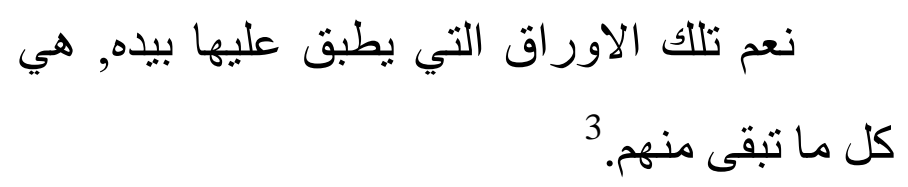

"It was not a dream, it was everyone, and it made him feel that his spirit wanted to leave his body to save him from it. Stopped at the beach. He got out of the car and started walking fast. It was as if he were throwing the same pressure that was suffocating him from his shoulders, leaving him motionless, as if he

حمد ابر اهيم "مأساة" 3 meant the sky to that far horizon. The sea was always a source of pain to him, reminding him of those who had gone to him and those who were dearest to him in his life. Only leaves are left of them. Yeah Al that sounds pretty crap to me, Looks like BT aint for me either" 4 .

From the above lines, it can be seen that the protagonist of the story is tired of the social environment in which he lives, and his spirit stops fighting. The spirit is also ready to leave the body. He is being chased by some force from outside, he is getting out of his car and speeding towards the beach where he always goes." They may be his relatives. Or creative people like him before. All they have left are the pages that the protagonist covers with both hands. Through the papers in the hands of the protagonist of the story, we perceive him as a creative person. Or maybe those pages are his memoirs, maybe the writings of his loved ones. That's why he's trying to preserve the leaves. Because only these leaves are left of them.

Life does not always give us what we want. Losing and finding is the law of life. The pages are his past, maybe his future. Everyone's life is actually a book. Its pages are every moment of our lives. The protagonist of the story is also a victim of the society in which he lived. He suffered so much from the community and its environment that he lost again and again. Towards the end of the story, the reader sees that the protagonist of the story is tired of fighting.

Indeed, the great Uzbek writer Utkir Hoshimov once said, "One ant can do nothing, and if all the ants unite, they will surely destroy the lion." No matter how hard the protagonist struggles with this society, no one hears his cry. In the end, he is doomed.

We know that the greatness of a creator is measured not only by the number and popularity of his works, but also by how he can say something new about life and man, how he can discover something new that has never been seen before. in this story, the

4 from that story 
CURRENT RESEARCH JOURNAL OF PHILOLOGICAL SCIENCES 2(8): 39-44,

May 2021 DOI: https://doi.org/10.37547/philological-crjps-02-08-10

ISSN 2767-3758

(C)2021 Master Journals

Crossref do: 81 Google

Accepted26 ${ }^{\text {th }}$ August, 2021 \& Published $31^{\text {th }}$ August, 2021

contradictions between man and man, man and society, man and being, are skillfully described. The mental state of the protagonist is expressed in an integral connection with nature.

Ahmad Ibrahim's story "Pain" is full of complex imagery. Therefore, the refinement of the intense tones, which are reflected in the evolution of his dark thoughts and reflections, reflects the color scheme. It, in turn, provides a deep imagery in the writer's stories. He creates stories in a magical lyrical spirit from a series of simple and straightforward thoughts. Words familiar to each of us have a deep intellectual power as well as expressing psychological experiences. Ahmad Ibrahim has a unique style of writing stories in a new poetic form.

When it comes to creative potential, the focus is not on what he describes, but on how he describes it.

\section{Discussion}

Ahmad Ibrahim made extensive use of artistic means in this story. For example, he used the arts of metaphor, allusion, and simile. These arts have added more charm, content, charm to his work.

The main point of this passage is that it is clear that a person will face death. Although the word death is not used, there is a reference to it in the phrase, "He who leads it in the way of truth for all."

The protagonist of the story, he inspects his life. The story is mainly a monologue of the protagonist. The protagonist's inner monologues reflect his spiritual experiences and rebellion.

The philosophical laws are also reflected in this story, that is, the law of negation. Time does not keep anyone. The writer sees the protagonist in the mirror and does not know how old he is. He talks to himself and looks at his life. leads to. This story of the author is reflected in Abdulla Aripov's poem "Autumn Landscapes", and in the poem "Huv anov shovallap okuchi soy, rider's life has an irreversible magic", he skillfully explains the transience of life as a running wind. Abdulla Aripov's poem "In the winds, I am like a wind, I came and went like the wind, I am leaving" is in harmony with the above verses.

Alisher Navoi is known to have four seasons of life, and he likens youth to the spring of life, free from all pains. Youth is a season of life that resists everything, overcomes difficulties and strengthens the will.

As every living soul tastes the fountain of life, one feels its taste and does not even know when it is the last drop of water. The protagonist, who is now facing the school of life at the end of his youth, says, "Suddenly I hit the truth." This is where the writer used the art of "imitation" from the art of painting. Indeed, a person who has gone through the innocence of youth now enters the stage called life. The protagonist, along with his dreams, records what he has achieved or failed to achieve in his lifetime. The culmination of the work, as we said at the beginning, is that the writer is currently living and working far away from where he was born and raised. He is living in exile far away from his homeland, he misses his homeland, he misses his friends and even the inability to carry his father's coffin. Here is the great statesman by king and poet Zahiriddin Muhammad Babur:

It's too late for me,

I made a mistake in everything I did,

I stayed where I was and went to India

I made a mistake in everything I did .

We know that the great king and poet Zahiriddin Muhammad Babur was also forced to live far from his homeland. Although he is a king in other lands, he always misses his homeland and the pain of living far away from it always torments him. Although he owns a great country like India, the dream of Samarkand, where he was born and grew up, will be his dream for the rest of his life.

This story is autobiographical. Because the writer himself lives and works far from the homeland, he misses the homeland, the pain of losing the homeland is described. Time also allows the protagonist to forget the person who addressed him as "you" before he died. Time steals everything from you and never comes back. It is safe to say that the author is the 
CURRENT RESEARCH JOURNAL OF PHILOLOGICAL SCIENCES 2(8): 39-44,

May 2021 DOI: https://doi.org/10.37547/philological-crjps-02-08-10

ISSN 2767-3758

(C)2021 Master Journals

Crossref do: 81 Google

Accepted26 ${ }^{\text {th }}$ August, 2021 \& Published $31^{\text {th }}$ August, 2021

protagonist of this story, he tried to end the transience of life with his sharp pen. As a person grows older, time seems to pass quickly. Have you ever noticed that a young girl becomes a bridesmaid or a doll and enters the image of a mother, which means that she is in a hurry to grow up. , can't appreciate everything.

Omar Khayyam says about the meaning of life:

Everyone is old and young -

It's all one after the other.

This world will last forever,

They're gone, we're leaving, they're coming, leaving .

V. CONCLUSION

In short, one of the highlights of Ahmad Ibrahim's story of "Pain" is that he created a story in the form of a poem. Ahmad Ibrahim's story "Pain" contains the idea of pain and sorrow. It reflects the author's spiritual forgiveness and the idea of a real event. It shows the superiority of the symbolic image style and the strength of generalizations of ideas, different moods, style of questioning, high level of emotion.

In this story, the author writes not only about his own pain, but also about the pain of humanity. the ideas of the story are more vivid and expressive. We see nostalgia in the heroic experiences of the author in this story. We did not compare the story to a work of poetry in vain. In this story, as in the poem, there is a mixture of thoughts and feelings, one grows from the heart, the other gives fluency to the image. The protagonist gives thanks, saying, "You have saved me from living far from home, from wandering, from suffering, from hardship."

The writer, originally from Iraq, currently lives and works far from his homeland. The main idea of his stories is the longing for the homeland, the contradictions between society and man, the feelings of the heart, the transience of life. The peculiarity of the writer's work is that although the form is reminiscent of poetry, it is in fact a prose. We got acquainted with Ahmad Ibrahim's work through his stories "Cry" and "Pain" in the collection of short stories "Return". The main content of the story "Cry" is the human psychology - it is the relationship between the individual and society. Through this story, we see the writer's inner experiences, heartache, and human psychology. In the story of "Pain" we see that the writer used a wide range of visual aids, skillfully used in this story such metaphors, metaphors, similes. Ahmad Ibrahim's story is about immigration, and we see nostalgia in the protagonist's experiences.

\section{REFERENCES}

1. A.Oripov. Tanlangan asarlar,T.2001. B.-375

2. Ahmedova Sh.I. Fors ko'rfazi arab mamlakatlari adabiyotida zamonaviy hikoyanavislikning rivojlanishi. ToshDShI //Arab adabiyoti. Sharq xalqlari adabiyoti tarixi. T.,2-jild. 2016. B.601-617

3. Akhmedova Sh.I. Narrative rpose in the arab countries of the persian gulf and features of its accelerated development. Literary Imagination. Issue 3 (2), Oxford University Press 2017.P 767-760

4. Anvar Hojiahmedov. She'r san'atlarini bilasizmi? - T.: "Sharq" nashriyot, -2001. - B.4.

5. Muhiddinova D.Z. " $\mathrm{XX}$ asr arab hikoyanavisligi ", monografiya; G'afur G'ulom nashriyoti. 2017. -222 b

6. Ramsay, Gail. Global heroes and local characters in short stories from the United Arab Emirates and the Sultanate of Oman // Middle Eastern literatures. Vol. 9, No. 2, August 2006.

7. Umar Xayyom. "Ruboiylar" to'plami T1995.B-1.

8. Xo'jaeva R. U. Yangi davr arab adabiyoti. O'quv qo'llanma. 1-qism. - T.: ToshDShI, 2004. - 178 b.

9. Zahiriddin Muhammad Bobur "Boburnoma" “O’qituvchi" " T. 2008.

10. Акбарова М. Х. Современные течения в арабской литературе. (XX пол. XX века). // ТошДши илмий мақолалар тўплами: 
CURRENT RESEARCH JOURNAL OF PHILOLOGICAL SCIENCES 2(8): 39-44,

May 2021 DOI: https://doi.org/10.37547/philological-crjps-02-08-10

ISSN 2767-3758

(C)2021 Master Journals

Crossref dof 81 Google

Accepted26 $6^{\text {th }}$ August, 2021 \& Published 31 ${ }^{\text {th }}$ August, 2021

$\begin{array}{ll}\text { Шарқ филологиясининг } & \text { тугун ва } \\ \text { эчимлари } & \text { (Проблемы } \\ \text { филологии). - Т.:, 2005. - С. 160. }\end{array}$

11. Крымский А.Е.История новой арабской литературы XIX- начало XX в. - М.: Наука, 1971. 